\title{
Characteristics of Culture Conditions for the Production of Biosurfactant by Bacillus pumilus IJ-1
}

\author{
Eunjin Park · Jiyeon Kim*
}

\section{Bacillus pumilus IJ-1의 생물계면활성제 생산을 위한 배양 특성}

박은진 · 김지연*

Received: 9 December 2014 / Accepted: 29 January 2015 / Published Online: 31 March 2015

(C) The Korean Society for Applied Biological Chemistry 2015

\begin{abstract}
To characterize the culture medium for the biosurfactant production by Bacillus pumilus IJ-1, the influences of various carbon, nitrogen and mineral sources were assessed. As a result, the highest biosurfactant production was observed after $96 \mathrm{~h}$ cultivation containing $0.5 \%(\mathrm{w} / \mathrm{v})$ tryptone. The strain was able to grow and produce biosurfactant at $0-10 \%(\mathrm{w} / \mathrm{v}) \mathrm{NaCl}$, in the $\mathrm{pH}$ range of $5-10$, and at $20-45^{\circ} \mathrm{C}$. Optimal culture conditions for the biosurfactant production were at $20^{\circ} \mathrm{C}$ and $\mathrm{pH} 9.0$ after 72 $\mathrm{h}$ incubation and the surface tension of biosurfactant was 27.0 dyne/cm.
\end{abstract}

Keywords Bacillus pumilus IJ-1 · biosurfactant $\cdot$ culture conditions - medium composition $\cdot$ surface tension

\section{서 론}

계면활성제(surfactant)는 한 분자 내에 친수성기(hydrophilic)와

\section{E. Park}

Department of Neuroscience, Graduate School, Inje University, Gimhae 621-749, Republic of Korea

J. Kim

College of General Education, Inje University, Gimhae 621-749, Republic of Korea

*Corresponding author (J. Kim: biokjy@inje.ac.kr)

This is an Open Access article distributed under the terms of the Creative Commons Attribution Non-Commercial License (http://creativecommons. org/licenses/by-nc/3.0/) which permits unrestricted non-commercial use, distribution, and reproduction in any medium, provided the original work is properly cited. 소수성기(hydrophobic)를 모두 갖는 양친매성 물질(amphipatic compound)로서 표면이나 계면의 성질을 변화시켜 표면장력을 감소시키는 물질이다(Deshpande 등, 1999). 이는 유화, 분산, 침 습, 습윤, 용해, 기포형성, 기포방지, 부식방지 등의 특성을 가 지고 있어 의약품, 식품, 화장품, 농약, 세제 및 각종 공업생산 공정뿐만 아니라, 최근에는 응용분야가 확장되어 microelectronics, 자기 기록 매체, 고급 전지, 전자 인쇄용 액체 인화제 등의 개 발과 연구에도 활용되고 있다(Banat 등, 2000). 이와 같이 다양 한 분야에 활용되고 있는 계면활성제는 대부분이 석유화학 제 품을 원료로 하여 화학적으로 합성된 화학합성 계면활성제 (chemical surfactant)로서 산업적으로 대량 생산되고 있다(Greek, 1991). 일반적으로 화학합성 계면활성제는 단가가 저렴하여 많 이 사용되지만, 대부분 독성이 강할 뿐만 아니라 난분해성으로 자연 생태계에 심각한 환경오염을 야기시킨다. 따라서 화학합성 계면활성제를 대체할 수 있는 새로운 계면활성제의 개발이 필 요하게 되었다. 이러한 화학합성 계면활성제의 문제점을 극복하 기 위하여 최근에는 미생물, 동물, 식물과 같은 생물 소재로부 터 얻어지는 생물계면활성제(biosurfactant)에 대한 연구가 주목 을 받고 있다(Hassanshahian 등, 2012).

지금까지 보고된 생물계면활성제는 세균(bacteria)과 곰팡이 (mold), 효모(yeast) 등 미생물 유래의 것이 대부분으로 균주에 따라 세포 외 또는 세포 내에 생산한다. 생물계면활성제는 화 학합성 계면활성제에 비해 독성이 적고 생분해가 용이한 친환 경적 물질로 그 사용가치가 매우 높다(Mukherjee 등, 2006). 뿐 만 아니라 생물계면활성제는 기존의 방법으로는 합성하기 어려 운 복잡한 화학 구조를 갖고 있어 특수한 목적으로 사용될 수 있고, 표면장력 저하능력, 온도, $\mathrm{pH}$ 에 대한 안정성 등 계면활성 제의 물리·화학적 면에서 기존의 화학합성 계면활성제와 거의 대등한 효과를 갖고 있어 사용가치가 매우 높은 물질이다 (Bognolo, 1999). 따라서 이와 같은 장점을 갖는 생물계면활성 제에 대한 연구가 전 세계적으로 활발하게 진행되어 많은 종류 의 생물계면활성제가 보고되었다. 이러한 성질로 인하여 생물계 
면활성제는 기존의 화학합성 계면활성제가 사용되는 대부분의 산업분야뿐 아니라 원유의 2차 회수, 펄프와 제지 산업, 육상과 해상의 유류 오염 정화, 처리조의 유지방 분해 등 다양한 분야 에서 그 응용이 점차 확대되고 있다(Banat 등, 2000; Mukherjee 등, 2006).

생물계면활성제를 생산하는 대표적인 미생물로는 Acinetobacter, Bacillus, Corynebacterium, Pseudomonas, Rhodococcus 등의 속(genus)들이 알려져 있다(Ahimou 등, 2000; Najkar와 Gutnick, 2003; Pirog 등, 2004; Thavasi 등, 2007; Sahoo 등, 2010). 현재 다양한 미생물에 의해 생산되는 생물계면활성제는 다양한 화학 구조를 갖고 있으며 glycolipids, lipopeptides, lipoproteins, neutral lipids, phospholipids, fatty acids와 lipopolysaccharides 등으로 분류된다(Banat 등, 2000).

실제 생물계면활성제의 공업적인 생산은 주로 미생물을 이용 하는 기술에 의존하고 있다. 미생물은 동 - 식물 세포에 비해 다루기가 쉽고, 미생물 종(species)에 따라 다양한 종류의 생물 계면활성제를 얻을 수 있으며, 생장속도가 다른 생물체보다 빨 라 단시일 내에 비교적 간단한 장치를 이용하여 다량의 생물계 면활성제를 생산할 수 있기 때문이다. 또한 배양과정이 비교적 간단하고, 포도당이나 탄화수소류(hydrocarbon)와 같은 다양한 기질을 이용하여 쉽게 대량생산 할 수 있다(Lang, 2002). 그러 나 화학합성 계면활성제에 비해 상대적으로 높은 생산비용과 생 물계면활성제를 대량생산할 때 발생하는 문제 등으로 인해 산 업적 이용이 부진한 실정이다. 이를 해결하기 위해서는 생산성 이 높은 균주의 확보, 배지 개발을 통한 수율 증가, 저렴한 발 효공정 개발 등이 필요하다(Mukherjee 등, 2006). 미생물에서의 생물계면활성제 생산 특성은 탄소원의 종류, 영양원의 제한, 탄 소원과 질소원의 비 및 질소원의 종류, $\mathrm{pH}$, 용존산소의 양, 온 도, 교반속도, 다가이온의 공급, 성장시기, 생산물에 의한 저해 작용 등 배양조건에 영향을 받으며, 생물계면활성의 증가 정도 는 표면장력의 감소능이나 유화능을 시험하여 알 수 있다 (Mukherjee 등, 2006).

본 연구자는 해양 원유 오염제거용 등 다양한 용도에 사용할 생물계면활성제 개발을 위해 태안의 원유 유출지역에서 원유분 해능이 우수한 Bacillus pumilus IJ-1을 분리하여 그 특성을 밝 힌 바 있다(Kim, 2014). 본 연구에서는 각종 인자(탄소원, 질소 원, 무기염, $\mathrm{NaCl}$ 농도, 배지의 초기 $\mathrm{pH}$, 배양 온도)에 따른 $B$. pumilus IJ-1의 생물계면활성제 생산 특성을 조사하여 효과적인 생물계면활성제 생산을 위한 기초 자료를 마련하고자 한다.

\section{재료 및 방법}

Biosurfactant 생산 균주 및 사용배지. 본 연구에서는 생물계면 활성제 생산 균주로서 Bacillus pumilus IJ-1을 사용하였다(Kim, 2014). B. pumilus IJ-1은 Luria-Bertani (LB) $[1.0 \%$ (w/v) tryptone (Difco, USA), $0.5 \%$ (w/v) yeast extract (BioShop ${ }^{\circledR}$, Canada), $1.0 \%(\mathrm{w} / \mathrm{v}) \mathrm{NaCl}\left(\mathrm{Bioshop}^{\circledR}\right)$, and $1.5 \%$ agar (w/w) (Difco), $\mathrm{pH}$ 7.0] 배지에서 배양하였다. 생물계면활성제 생산을 위한 배 지로는 무기염류 배지인 $\mathrm{A}$-배지 $\left[0.3 \%(\mathrm{w} / \mathrm{v}) \mathrm{KNO}_{3}, 0.22 \%\right.$ (w/v) $\mathrm{Na}_{2} \mathrm{HPO}_{4}, 0.014 \%$ (w/v) $\mathrm{KH}_{2} \mathrm{PO}_{4}, 0.001 \%$ (w/v) $\mathrm{NaCl}$, $0.06 \%$ (w/v) $\mathrm{MgSO}_{4}, 0.004 \%$ (w/v) $\mathrm{CaCl}_{2}, 0.002 \%$ (w/v) $\mathrm{FeSO}_{4}$, and $0.1 \mathrm{~mL}$ of a trace element solution containing $(\mathrm{g} / \mathrm{L})$ : $2.32 \mathrm{~g} \mathrm{ZnSO}_{4} \cdot 7 \mathrm{H}_{2} \mathrm{O}, 1.78 \mathrm{~g} \mathrm{MnSO}_{4} \cdot 4 \mathrm{H}_{2} \mathrm{O}, 0.56 \mathrm{~g} \mathrm{H}_{3} \mathrm{BO}_{3}, 1 \mathrm{~g}$
$\mathrm{CuSO}_{4} \cdot 5 \mathrm{H}_{2} \mathrm{O}, \quad 0.39 \mathrm{~g} \quad \mathrm{Na}_{2} \mathrm{MoO}_{4} \cdot 2 \mathrm{H}_{2} \mathrm{O}, \quad 0.42 \mathrm{~g} \quad \mathrm{CoCl}_{2} \cdot 6 \mathrm{H}_{2} \mathrm{O}$, and $1 \mathrm{~g} \mathrm{EDTA}$ ]를 사용하였다(Hur 등, 2002).

배양 조건. 생물계면활성제 생산을 위해 B. pumilus IJ-1을 LB 액체 배지 $(\mathrm{pH} 7.0)$ 에 접종하여 균주 생장의 최적 온도인 $35^{\circ} \mathrm{C}$ 에서 $200 \mathrm{rpm}$ 으로 16 시간 동안 종 배양(seed culture)하였다. 생 물계면활성제 생산을 위해 생장된 균주를 A-배지에 $1.0 \%(\mathrm{v} / \mathrm{v})$ 되게 접종하고, $35^{\circ} \mathrm{C}$ 에서 $200 \mathrm{rpm}$ 으로 96 시간 동안 진탕 배양 하였다.

균주 생장 측정. B. pumilus IJ-1의 생장 측정은 간접계수 방법 으로 BioPhotometer 6131 spectrophotometer (Eppendorf AG, Eppendorf, Germany)를 이용한 흡광도(optimal density)를 $600 \mathrm{~nm}$ 에서 측정하였다.

생물계면활성제 분리. 생물계면활성제는 Ghojavand 등(2008)의 방법을 변형하여 분리하였다. 종 배양액을 생물계면활성제 생산 배지에 $1.0 \%(\mathrm{v} / \mathrm{v})$ 접종하여 $35^{\circ} \mathrm{C}$ 에서 96 시간 동안 진탕 배양 하였다. 진탕 배양한 균주의 배양액을 원심분리 $\left(4^{\circ} \mathrm{C}, 10,000\right.$ $\mathrm{rpm}, 20$ 분)하여 균체를 제거한 상등액에 $6.0 \mathrm{M} \mathrm{HCl}$ 을 서서히 가하면서 $\mathrm{pH}$ 가 2.0 이 되게 조정하여 $4^{\circ} \mathrm{C}$ 에 하룻밤 방치하면서 생물계면활성제를 침전시켰다. 이를 원심분리하여 침전물을 회 수하고, 알칼리성 수용액 $(0.1 \mathrm{~N} \mathrm{NaOH})$ 에 최종 $\mathrm{pH} 8.0$ 이 되게 용해하여 동결건조 시켰다. 건조된 물질을 $10 \mathrm{~mL}$ 의 methanol로 3 회 추출하여 농축한 것을 생물계면활성제로 사용하였다(Kim, 2014).

표면장력 측정. 표면장력은 성격이 다른 두 상이 서로 인접하 고 있을 때, 액체의 자유표면에서 표면을 작게 하려고 작용하 는 장력이며, 미생물이 생물계면활성제를 생산하면 표면장력은 떨어진다. 이 사실을 이용해 표면장력 값으로 미생물이 생산하 는 생물계면활성제의 표면장력 활성을 확인하였다(Lang, 2002). 표면장력은 Surface Tension Analyzer DST-60 (Surface Electro Optics Co., Korea)을 사용, ring 방법으로 $25^{\circ} \mathrm{C}$ 에서 3 회 반복 하여 측정하고, 그 평균값을 계산하였다(Pagilla 등, 2002).

생물계면활성제 생산을 위한 각종 탄소원의 영향 조사. 생물계 면활성제 생산에 가장 큰 영향을 미치는 질소원에 대한 각종 탄소원의 영향을 조사하기 위하여 $0.5 \%(\mathrm{w} / \mathrm{v})$ tryptone이 첨가 된 $\mathrm{A}$-배지에 각종 탄소원(총 28종)으로 당류(sugars) 또는 탄수 화물(carbohydrates)인 arabinose, carboxymethyl cellulose (CMC), dextrose, fructose, galactose, glucose, glycerol, lactose, maltose, mannitol, mannose, raffinose, soluble starch, sucrose, trehalose, xylose와 hydrocarbon류인 pentane $\left(\mathrm{C}_{5}\right)$, hexane $\left(\mathrm{C}_{6}\right)$, heptane $\left(\mathrm{C}_{7}\right)$, octane $\left(\mathrm{C}_{8}\right)$, nonane $\left(\mathrm{C}_{9}\right)$, decane $\left(\mathrm{C}_{10}\right)$, tetradecane $\left(\mathrm{C}_{14}\right)$, hexadecane $\left(\mathrm{C}_{16}\right)$, crude oil (produced in Kuwait), polyaromatic hydrocarbons $(\mathrm{PAH})$ 류인 benzene $\left(\mathrm{C}_{6} \mathrm{H}_{6}\right)$, toluene $\left(\mathrm{C}_{7} \mathrm{H}_{8}\right)$, paraffin $\left(\mathrm{C}_{\mathrm{n}} \mathrm{H}_{2 \mathrm{n}+2}\right)$ 을 각 $0.5 \%(\mathrm{w} / \mathrm{v}$ 또는 $\mathrm{v} / \mathrm{v})$ 씩 첨가하 여 $35^{\circ} \mathrm{C}, 200 \mathrm{rpm}$ 으로 96 시간 동안 배양하여 균주의 생장과 표 면장력을 측정하였다. 표면장력을 측정한 값은 각 탄소원에 따 라 초기 표면장력 값이 다르므로 초기 표면장력 값과 최종 표 면장력의 값의 차이 즉, 표면장력 감소율을 계산하여 표기하였다. 생물계면활성제 생산을 위한 각종 질소원의 영향 조사. 생물계 면활성제 생산에 가장 큰 영향을 미치는 탄소원에 대한 각종 질소원의 영향을 조사하기 위하여 $0.5 \%(\mathrm{v} / \mathrm{v})$ glycerol이 첨가 된 A-배지에 각종 유기 질소원(beef extract, casein, malt extract, peptone, skim milk, soytone, tryptone, yeast extract)과 무기 질소원 $\left[\left(\mathrm{NH}_{4}\right) \mathrm{H}_{2} \mathrm{PO}_{4}, \mathrm{NH}_{4} \mathrm{Cl}, \mathrm{NH}_{4} \mathrm{NO}_{3},\left(\mathrm{NH}_{4}\right) \mathrm{O}_{2} \mathrm{SO}_{4}, \mathrm{KNO}_{3}\right.$, $\mathrm{NaNO}_{3}$ ]을 각 $0.5 \%(\mathrm{w} / \mathrm{v})$ 첨가하여 $35^{\circ} \mathrm{C}, 200 \mathrm{rpm}$ 으로 96시간 
동안 배양하여 균주의 생장과 표면장력을 측정하였다. 표면장력 을 측정한 값은 각 질소원에 따라 초기 표면장력 값이 다르므 로 초기 표면장력 값과 최종 표면장력의 값의 차이 즉, 표면장 력 감소율을 계산하여 표기하였다.

생물계면활성제 생산을 위한 각종 무기염의 영향 조사. 생물계 면활성제 생산을 위한 무기염의 영향을 조사하기 위해 $0.5 \%$ $(\mathrm{w} / \mathrm{v})$ tryptone이 첨가된 $\mathrm{A}$-배지에 각종 무기염류 총 15 종 $\left(\mathrm{CaCl}_{2}, \mathrm{CaCO}_{3}, \mathrm{CoCl}_{2}, \mathrm{CuSO}_{4}, \mathrm{~K}_{2} \mathrm{HPO}_{4}, \mathrm{KCl}, \mathrm{KH}_{2} \mathrm{PO}_{4}\right.$, $\mathrm{MgSO}_{4}, \mathrm{MnSO}_{4}, \mathrm{NaCl}, \mathrm{KNO}_{3}, \mathrm{Na}_{2} \mathrm{HPO}_{4}, \mathrm{FeSO}_{4}, \mathrm{H}_{3} \mathrm{BO}_{3}$, $\left.\mathrm{Na}_{2} \mathrm{MoO}_{4}\right)$ 을 각 $0.1 \%(\mathrm{w} / \mathrm{v})$ 농도가 되도록 첨가하여 $35^{\circ} \mathrm{C}$, $200 \mathrm{rpm}$ 으로 96시간 동안 배양하여 균주 생장과 표면장력을 측 정하였다. 표면장력을 측정한 값은 각 무기염류에 따라 초기 표 면장력 값이 다르므로 초기 표면장력 값과 최종 표면장력의 값 의 차이 즉, 표면장력 감소율을 계산하여 표기하였다.

생물계면활성제 생산을 위한 $\mathrm{NaCl}$ 농도의 영향 조사. 다양한 $\mathrm{NaCl}$ 농도에 따른 생물계면활성제 생산을 조사하기 위하여 $0.5 \%(\mathrm{w} / \mathrm{v})$ tryptone이 첨가된 $\mathrm{A}$-배지에 $\mathrm{NaCl}$ 의 농도가 각각 $0,1,2,3,4,5,6,7,8,9,10 \%(\mathrm{w} / \mathrm{v})$ 가 되도록 준비하였다. 종 배양액을 다양한 $\mathrm{NaCl}$ 농도의 배지에 각각 $1.0 \%(\mathrm{v} / \mathrm{v})$ 로 접 종하여 $35^{\circ} \mathrm{C}, 200 \mathrm{rpm}$ 으로 진탕 배양하면서 12 시간 간격으로 균주의 생장과 생물계면활성제의 표면장력을 측정하였다.

생물계면활성제 생산을 위한 초기 $\mathrm{pH}$ 의 영향 조사. 배지의 다 양한 초기 $\mathrm{pH}$ 에 따른 생물계면활성제 생산을 조사하기 위하여 $0.5 \%(\mathrm{w} / \mathrm{v})$ tryptone이 첨가된 배지에 $1.0 \mathrm{~N} \mathrm{HCl}$ 과 $1.0 \mathrm{~N}$ $\mathrm{NaOH}$ 를 각각 첨가하여 $\mathrm{pH}$ 3에서 $\mathrm{pH} 10$ 까지 각각 $\mathrm{pH} 1.0$ 간 격으로 조정하였다. 종 배양액을 다양한 $\mathrm{pH}$ 범위의 배지에 각 $1.0 \%(\mathrm{v} / \mathrm{v})$ 로 접종하여 $35^{\circ} \mathrm{C}, 200 \mathrm{rpm}$ 으로 진탕 배양하면서 12 시간 간격으로 균주의 생장과 생물계면활성제의 표면장력을 측 정하였다.

생물계면활성제 생산을 위한 온도의 영향 조사. 다양한 배양 온 도에 따른 생물계면활성제 생산을 조사하기 위하여 B. pumilus $\mathrm{IJ}-1$ 종 배양액을 $0.5 \%(\mathrm{w} / \mathrm{v})$ tryptone이 첨가된 배지에 $1.0 \%$ $(\mathrm{v} / \mathrm{v})$ 접종하여 각각 $15-50^{\circ} \mathrm{C}$ 까지 $5^{\circ} \mathrm{C}$ 간격으로 96 시간 동안 $200 \mathrm{rpm}$ 으로 진탕 배양하면서 12시간 마다 균주의 생장과 생물 계면활성제의 표면장력을 측정하였다.

통계처리. 모든 결과는 3 회 이상 독립적으로 수행한 실험결과 로서, 이들의 평균(mean)과 표준편차(standard deviation, SD)를 산출하여 결과를 나타내었다. 실험결과의 통계처리는 Student's t-test에 준하여 처리하였으며, $p$-value가 최대치 0.05 미만 $(p<0.05)$ 인 경우를 유의한 것으로 판정하였다.

\section{결과 및 고찰}

B. pumilus IJ-1의 생물계면활성제 생산에 미치는 탄소원의 영 향. 생물계면활성제 생산을 증가시키려는 노력에도 불구하고 화 학합성 계면활성제와 대체되지 못하고 있는 이유는 생물계면활 성제를 생산하는 균주 마다 상이한 환경을 요구하고, 탄소원과 질소원, 무기염을 이용하는데 많은 비용이 소요되기 때문이다 (Bognolo, 1999). 따라서 생물계면활성제 생산을 위한 최적 배 지 조성과 환경 조건(온도, $\mathrm{pH}$, 통기량, 염 농도 등)을 반드시 검토해야 한다.

많은 연구자들은 Bacillus의 생장과 생물계면활성제 생산에 영향을 미치는 탄소원에 대해 보고한 바 있다(Kim 등, 1997;
Makkar와 Cameotra, 1998; Joshi 등, 2008; Haddad 등, 2009). 그러나 이들은 균주가 한가지 기질을 탄소원으로 이용하였을 때 생물계면활성제 생산에 미치는 영향을 보고한 것으로, 본 연구 에서는 다양한 배양조건에 따라 생물계면활성제 생산이 달라질 수 있다는 것을 조사하기 위해 질소원에 대한 각종 탄소원의 영향을 검토하였다.

본 연구자의 연구 결과(Kim, 2014)에 의하면 B. pumilus IJ1 의 생물계면활성제 생산에 가장 많은 영향을 미치는 질소원은 $0.5 \%$ (w/v) tryptone으로 조사되었다. 따라서 본 연구에서는 tryptone의 농도를 $0.5 \%(\mathrm{w} / \mathrm{v})$ 로 고정하고 다양한 탄소원을 각

Table 1 Effect of different carbon sources on the cell growth and surface tension of the biosurfactant produced by B. pumilus IJ-1

\begin{tabular}{|c|c|c|c|c|}
\hline \multirow{2}{*}{$\begin{array}{l}\text { Carbon source } \\
\qquad(0.5 \%, \\
\text { w/v or v/v) }\end{array}$} & \multirow{2}{*}{$\begin{array}{l}\text { Cell growth } \\
\left(\mathrm{OD}_{600}\right)\end{array}$} & \multicolumn{2}{|c|}{$\begin{array}{l}\text { Surface tension of } \\
\text { culture supernatant } \\
(\text { dyne } / \mathrm{cm})\end{array}$} & \multirow{2}{*}{$\begin{array}{l}\text { Reduction of } \\
\text { surface } \\
\text { tension } \\
(\%)\end{array}$} \\
\hline & & Initial & Final & \\
\hline $\begin{array}{l}0.5 \%(\mathrm{w} / \mathrm{v}) \\
\text { of tryptone } \\
\text { (control) }\end{array}$ & $2.188 \pm 0.004$ & $57.3 \pm 0.22$ & $27.5 \pm 0.05$ & 52.0 \\
\hline Arabinose & $1.239 \pm 0.003$ & $60.4 \pm 0.36$ & $36.6 \pm 0.30 *$ & 39.4 \\
\hline $\begin{array}{l}\text { Carboxymethyl } \\
\text { cellulose } \\
\text { (CMC) }\end{array}$ & $2.322 \pm 0.006$ & $58.2 \pm 0.05$ & $31.7 \pm 0.25^{*}$ & 45.5 \\
\hline Dextrose & $2.918 \pm 0.007$ & $61.5 \pm 0.27$ & $38.4 \pm 0.35^{*}$ & 37.6 \\
\hline Fructose & $2.574 \pm 0.007$ & $59.8 \pm 0.14$ & $35.6 \pm 0.34 *$ & 40.5 \\
\hline Galactose & $1.165 \pm 0.005$ & $50.9 \pm 0.05$ & $33.5 \pm 0.13 *$ & 34.2 \\
\hline Glucose & $3.025 \pm 0.008$ & $61.5 \pm 0.19$ & $35.8 \pm 0.00^{*}$ & 41.8 \\
\hline Glycerol & $2.858 \pm 0.003$ & $57.8 \pm 0.14$ & $56.5 \pm 0.18^{*}$ & 2.2 \\
\hline Lactose & $1.655 \pm 0.003$ & $61.2 \pm 0.14$ & $39.6 \pm 0.21 *$ & 35.3 \\
\hline Maltose & $1.102 \pm 0.008$ & $59.5 \pm 0.42$ & $39.3 \pm 0.05^{*}$ & 33.9 \\
\hline Mannitol & $2.938 \pm 0.007$ & $53.6 \pm 0.31$ & $34.7 \pm 0.00 *$ & 35.3 \\
\hline Mannose & $3.011 \pm 0.008$ & $53.2 \pm 0.00$ & $36.9 \pm 0.05^{*}$ & 30.6 \\
\hline Raffinose & $1.091 \pm 0.003$ & $60.1 \pm 0.05$ & $32.6 \pm 0.05^{*}$ & 45.6 \\
\hline Soluble starch & $5.290 \pm 0.001$ & $59.9 \pm 0.00$ & $35.3 \pm 0.30^{*}$ & 41.1 \\
\hline Sucrose & $1.269 \pm 0.003$ & $54.6 \pm 0.26$ & $52.9 \pm 0.18^{*}$ & 3.1 \\
\hline Trehalose & $2.101 \pm 0.006$ & $62.2 \pm 0.19$ & $43.6 \pm 0.13^{*}$ & 30.0 \\
\hline Xylose & $1.849 \pm 0.007$ & $54.6 \pm 0.31$ & $32.4 \pm 0.36^{*}$ & 40.7 \\
\hline Pentane & $1.800 \pm 0.005$ & $52.9 \pm 0.20$ & $35.7 \pm 0.21^{*}$ & 32.5 \\
\hline Hexane & $2.202 \pm 0.003$ & $31.7 \pm 0.25$ & $31.6 \pm 0.00^{*}$ & 0.3 \\
\hline Heptane & $1.767 \pm 0.005$ & $50.8 \pm 0.05$ & $47.5 \pm 0.20 *$ & 6.5 \\
\hline Octane & $1.429 \pm 0.007$ & $53.4 \pm 0.18$ & $45.0 \pm 0.05^{*}$ & 15.7 \\
\hline Nonane & $1.177 \pm 0.002$ & $49.3 \pm 0.27$ & $41.4 \pm 0.30^{*}$ & 16.0 \\
\hline Decane & $1.374 \pm 0.007$ & $48.7 \pm 0.05$ & $44.0 \pm 0.28 *$ & 9.7 \\
\hline Tetradecane & $3.158 \pm 0.008$ & $50.7 \pm 0.13$ & $35.6 \pm 0.17^{*}$ & 29.8 \\
\hline Hexadecane & $1.250 \pm 0.001$ & $44.5 \pm 0.09$ & $36.9 \pm 0.00 *$ & 17.1 \\
\hline Crude oil & $6.728 \pm 0.006$ & $48.6 \pm 0.31$ & $45.7 \pm 0.25^{*}$ & 6.0 \\
\hline Benzene & $2.792 \pm 0.001$ & $62.2 \pm 0.16$ & $49.7 \pm 0.26^{*}$ & 20.1 \\
\hline Toluene & $0.044 \pm 0.006$ & $58.9 \pm 0.05$ & $55.2 \pm 0.29^{*}$ & 6.3 \\
\hline Paraffin & $2.781 \pm 0.004$ & $62.2 \pm 0.18$ & $33.3 \pm 0.13^{*}$ & 46.5 \\
\hline
\end{tabular}

Seed culture $(1 \mathrm{~mL})$ was inoculated into $100 \mathrm{~mL}$ of A-medium containing $0.5 \%(\mathrm{w} / \mathrm{v})$ of tryptone as a control and A-medium containing $0.5 \%(\mathrm{w} /$ v) of tryptone supplemented with $0.5 \%(\mathrm{w} / \mathrm{v})$ of each carbon source. Cultivation was carried out for $96 \mathrm{~h}$ at $35^{\circ} \mathrm{C}, 200 \mathrm{rpm}$. Results represent the average of three independent experiments. Values were means of three determinations in five parallel experiments ( \pm standard deviations). * Statistically significant compared with the control $(* p<0.05)$. 
각 $0.5 \%(\mathrm{w} / \mathrm{v}$ 또는 $\mathrm{v} / \mathrm{v})$ 가 되도록 첨가하여 질소원에 대한 각 종 탄소원의 영향을 검토하였다(Table 1). 첨가된 탄소원의 종 류에 따라 초기 표면장력 값이 다르므로 B. pumilus IJ-1의 배 양 전 초기 표면장력 값과 배양 후 최종 표면장력 값의 차이 즉, 표면장력 감소율 $(\%)$ 을 계산하여 표기하였다.

균주 생장은 crude oil $\left(\mathrm{OD}_{600}=6.728\right)$, soluble starch $\left(\mathrm{OD}_{600}\right.$ $=5.290)$ 순으로 높게 나타났다. 표면장력 감소율을 검토한 결과 paraffin (33.3 $\pm 0.13, p<0.05)$ 과 raffinose $(32.6 \pm 0.05, p<0.05)$, $\mathrm{CMC}(31.7 \pm 0.25, p<0.05)$ 에서는 각각 $46.5,45.6,45.5 \%$ 순 으로 높게 조사되었으나, 이들은 모두 대조구 $(52.0 \%)$ 보다 낮은 것으로 확인되었다. 따라서 질소원인 $0.5 \%(\mathrm{w} / \mathrm{v})$ tryptone에 각 종 탄소원을 첨가한 배지는 B. pumilus IJ-1의 생물계면활성제 생산을 증가시키는데 적합하지 않은 것으로 나타났다.

B. pumilus IJ-1의 생물계면활성제 생산에 미치는 질소원의 영 향. 배지 조성 중 질소원은 생물계면활성제 생산에 많은 영향 을 미치는 중요 인자로 알려졌다. 많은 연구자들은 Bacillus의 생장과 생물계면활성제 생산에 영향을 미치는 질소원에 대해 보 고하였다(Makkar와 Cameotra, 1998; Haddad 등, 2009). 그러 나 이들은 생물계면활성제 생산에 대한 한가지 기질인 질소원 에 대해서만 조사한 것이다. 본 연구에서는 다양한 배양조건에 따라 생물계면활성제 생산이 달라질 수 있다는 것을 조사하기 위해 최적 탄소원에 대한 각종 질소원의 영향을 검토하였다.

앞서 보고한 연구결과(Kim, 2014)에 의하면 B. pumilus IJ-1

Table 2 Effect of different nitrogen sources on the cell growth and surface tension of the biosurfactant produced by B. pumilus IJ-1

\begin{tabular}{|c|c|c|c|c|}
\hline \multirow[t]{2}{*}{$\begin{array}{c}\text { Nitrogen source } \\
(0.5 \%, \mathrm{w} / \mathrm{v})\end{array}$} & \multirow[t]{2}{*}{$\begin{array}{l}\text { Cell growth } \\
\left(\mathrm{OD}_{600}\right)\end{array}$} & \multicolumn{2}{|c|}{$\begin{array}{l}\text { Surface tension of } \\
\text { culture supernatant } \\
\quad(\text { dyne } / \mathrm{cm})\end{array}$} & \multirow{2}{*}{$\begin{array}{l}\text { Reduction of } \\
\text { surface } \\
\text { tension } \\
(\%)\end{array}$} \\
\hline & & Initial & Final & \\
\hline $\begin{array}{l}0.5 \%(\mathrm{v} / \mathrm{v}) \\
\text { glycerol } \\
\text { (control) }\end{array}$ & $0.670 \pm 0.006$ & $72.5 \pm 0.05$ & $39.7 \pm 0.10$ & 45.2 \\
\hline \multicolumn{5}{|c|}{ Complex nitrogen sources: } \\
\hline Beef extract & $0.452 \pm 0.008$ & $48.6 \pm 0.30$ & $45.6 \pm 0.23^{*}$ & 6.2 \\
\hline Casein & $1.926 \pm 0.008$ & $46.9 \pm 0.10$ & $40.8 \pm 0.10^{*}$ & 13.0 \\
\hline Malt extract & $0.356 \pm 0.002$ & 52. $2 \pm 0.15$ & $48.1 \pm 0.18^{*}$ & 7.9 \\
\hline Peptone & $1.023 \pm 0.003$ & $54.3 \pm 0.10$ & $47.6 \pm 0.18^{*}$ & 12.8 \\
\hline Skim milk & $0.205 \pm 0.003$ & $47.3 \pm 0.00$ & $37.6 \pm 0.30^{*}$ & 20.5 \\
\hline Soytone & $2.370 \pm 0.007$ & $53.9 \pm 0.09$ & $38.9 \pm 0.05^{*}$ & 27.8 \\
\hline Tryptone & $2.858 \pm 0.006$ & $57.8 \pm 0.14$ & $56.5 \pm 0.18^{*}$ & 2.2 \\
\hline Yeast extract & $1.920 \pm 0.002$ & $56.7 \pm 0.18$ & $36.5 \pm 0.17 *$ & 35.6 \\
\hline \multicolumn{5}{|c|}{ Inorganic nitrogen sources: } \\
\hline$\left(\mathrm{NH}_{4}\right) \mathrm{H}_{2} \mathrm{PO}_{4}$ & $0.617 \pm 0.005$ & $71.5 \pm 0.24$ & $44.6 \pm 0.45^{*}$ & 37.6 \\
\hline $\mathrm{NH}_{4} \mathrm{Cl}$ & $0.720 \pm 0.009$ & $69.7 \pm 0.27$ & $39.3 \pm 0.26^{*}$ & 43.6 \\
\hline $\mathrm{NH}_{4} \mathrm{NO}_{3}$ & $0.662 \pm 0.005$ & $64.9 \pm 0.05$ & $55.3 \pm 0.33^{*}$ & 14.8 \\
\hline$\left(\mathrm{NH}_{4}\right) \mathrm{O}_{2} \mathrm{SO}_{4}$ & $0.612 \pm 0.004$ & $64.7 \pm 0.09$ & $47.7 \pm 0.30^{*}$ & 26.3 \\
\hline $\mathrm{KNO}_{3}$ & $0.551 \pm 0.003$ & $67.1 \pm 0.21$ & $41.4 \pm 0.47^{*}$ & 38.3 \\
\hline $\mathrm{NaNO}_{3}$ & $0.216 \pm 0.003$ & $66.4 \pm 0.24$ & $39.9 \pm 0.05^{*}$ & 39.9 \\
\hline
\end{tabular}

Seed culture $(1 \mathrm{~mL})$ was inoculated into $100 \mathrm{~mL}$ of A-medium containing $0.5 \%(\mathrm{v} / \mathrm{v})$ of glycerol as a control and A-medium containing $0.5 \%(\mathrm{v} / \mathrm{v})$ of glycerol supplemented with $0.5 \%(\mathrm{w} / \mathrm{v})$ of each nitrogen source. Cultivation was carried out for $96 \mathrm{~h}$ at $35^{\circ} \mathrm{C}, 200 \mathrm{rpm}$. Results represent the average of three independent experiments. Values were means of three determinations in five parallel experiments ( \pm standard deviations). *Statistically significant compared with the control $\left({ }^{*} p<0.05\right)$.
의 생물계면활성제 생산에 가장 많은 영향을 미치는 탄소원은 $0.5 \%$ (v/v) glycerol로 조사되었다. 따라서 본 연구에서는 glyceroloㅢ 농도를 $0.5 \%(\mathrm{v} / \mathrm{v})$ 로 고정하고 다양한 질소원을 각 각 $0.5 \%(\mathrm{w} / \mathrm{v})$ 가 되도록 첨가하여 탄소원에 대한 각종 질소원 의 영향을 검토하였다(Table 2). 질소원 종류에 따라 초기 표면 장력 값이 다르므로 배양 전 초기 표면장력 값과 배양 후 최종 표면장력 값의 차이, 즉 표면장력 감소율을 계산하여 표기하였다.

B. pumilus $\mathrm{IJ}-1$ 은 무기 질소원보다 유기 질소원에서 더 잘 생장하였으며, 그 중 tryptone에서 가장 높은 생장을 나타내었 다. 표면장력 감소율은 $\mathrm{NH}_{4} \mathrm{Cl}$ 을 첨가한 배지에서 $43.6 \%$ 로 가 장 높았고(39.3 $\pm 0.26, p<0.05)$, tryptone을 첨가한 배지에서는 $2.2 \%$ 로 가장 낮게 나타났다 $(56.5 \pm 0.18, p<0.05)$. 한편, $0.5 \%$ $(\mathrm{v} / \mathrm{v})$ glycerol에 각종 질소원을 첨가한 배지의 표면장력은 대조 구보다 모두 낮은 것으로 확인되었으며, 대조군에 비해 모두 유 의적인 차이를 나타내었다 $\left({ }^{*} p<0.05\right)$. 따라서 탄소원 $0.5 \%(\mathrm{v} / \mathrm{v})$ glycerol에 각종 질소원을 첨가한 배지는 B. pumilus $\mathrm{IJ}-1$ 의 생 물계면활성제 생산을 증가시키는데 적합하지 않은 것으로 조사 되었다.

B. pumilus IJ-1의 생물계면활성제 생산에 미치는 무기염의 영 향. 무기염류는 균주의 생장과 생물계면활성제 생산에 상당히 많은 영향을 미친다. 무기염이 B. pumilus IJ-1의 생물계면활성 제 생산에 미치는 영향을 알아보기 위하여 생물계면활성제 생 산에 가장 많은 영향을 미치는 $0.5 \%(\mathrm{w} / \mathrm{v})$ tryptone이 함유된 $\mathrm{A}$-배지에 각종 무기염을 최종 농도 $0.1 \%(\mathrm{w} / \mathrm{v})$ 가 되도록 첨가

Table 3 Effect of different mineral sources on the cell growth and surface tension of the biosurfactant produced by B. pumilus IJ-1

\begin{tabular}{|c|c|c|c|c|}
\hline \multirow{2}{*}{$\begin{array}{c}\text { Mineral } \\
\text { sources } \\
(0.1 \%, w / v)\end{array}$} & \multirow[t]{2}{*}{$\begin{array}{l}\text { Cell growth } \\
\left(\mathrm{OD}_{600}\right)\end{array}$} & \multicolumn{2}{|c|}{$\begin{array}{l}\text { Surface tension of } \\
\text { culture supernatant } \\
\quad(\text { dyne } / \mathrm{cm})\end{array}$} & \multirow{2}{*}{$\begin{array}{l}\text { Reduction of } \\
\text { surface } \\
\text { tension }(\%)\end{array}$} \\
\hline & & Initial & Final & \\
\hline $\begin{array}{l}0.5 \%(\mathrm{w} / \mathrm{v}) \text { of } \\
\text { tryptone } \\
(\text { control })\end{array}$ & $2.188 \pm 0.004$ & $57.3 \pm 0.22$ & $27.5 \pm 0.05$ & 52.0 \\
\hline $\mathrm{CaCl}_{2}$ & $0.897 \pm 0.002$ & $60.5 \pm 0.05$ & $59.1 \pm 0.10^{*}$ & 2.3 \\
\hline $\mathrm{CaCO}_{3}$ & $0.017 \pm 0.001$ & $60.9 \pm 0.05$ & $47.5 \pm 0.46^{*}$ & 22.0 \\
\hline $\mathrm{CoCl}_{2}$ & $0.058 \pm 0.002$ & $59.8 \pm 0.09$ & $58.7 \pm 0.10^{*}$ & 1.8 \\
\hline $\mathrm{CuSO}_{4}$ & $0.011 \pm 0.001$ & $57.4 \pm 0.10$ & $56.6 \pm 0.13^{*}$ & 1.4 \\
\hline $\mathrm{K}_{2} \mathrm{HPO}_{4}$ & $0.520 \pm 0.003$ & $59.9 \pm 0.10$ & $37.5 \pm 0.38^{*}$ & 37.4 \\
\hline $\mathrm{KCl}$ & $0.349 \pm 0.004$ & $60.8 \pm 0.05$ & $33.6 \pm 0.26^{*}$ & 44.7 \\
\hline $\mathrm{KH}_{2} \mathrm{PO}_{4}$ & $0.297 \pm 0.004$ & $60.1 \pm 0.09$ & $35.8 \pm 0.14^{*}$ & 40.4 \\
\hline $\mathrm{MgSO}_{4}$ & $0.838 \pm 0.003$ & $60.6 \pm 0.30$ & $37.6 \pm 0.12 *$ & 38.0 \\
\hline $\mathrm{MnSO}_{4}$ & $0.021 \pm 0.002$ & $60.6 \pm 0.15$ & $57.7 \pm 0.28^{*}$ & 4.8 \\
\hline $\mathrm{NaCl}$ & $0.815 \pm 0.004$ & $59.7 \pm 0.17$ & $32.8 \pm 0.21 *$ & 45.1 \\
\hline $\mathrm{KNO}_{3}$ & $0.412 \pm 0.003$ & $60.8 \pm 0.15$ & $34.4 \pm 0.35^{*}$ & 43.4 \\
\hline $\mathrm{Na}_{2} \mathrm{HPO}_{4}$ & $0.314 \pm 0.002$ & $58.6 \pm 0.23$ & $36.8 \pm 0.12 *$ & 37.2 \\
\hline $\mathrm{FeSO}_{4}$ & $0.634 \pm 0.001$ & $59.9 \pm 0.05$ & $59.6 \pm 0.13 *$ & 0.5 \\
\hline $\mathrm{H}_{3} \mathrm{BO}_{3}$ & $0.657 \pm 0.004$ & $59.8 \pm 0.00$ & $34.0 \pm 0.05^{*}$ & 43.1 \\
\hline $\mathrm{Na}_{2} \mathrm{MoO}_{4}$ & $0.362 \pm 0.002$ & $60.1 \pm 0.09$ & $34.5 \pm 0.25^{*}$ & 42.6 \\
\hline
\end{tabular}

Seed culture $(1 \mathrm{~mL})$ was inoculated into $100 \mathrm{~mL}$ of A-medium containing $0.5 \%(\mathrm{w} / \mathrm{v})$ of tryptone as a control and A-medium containing $0.5 \%(\mathrm{w} /$ v) of tryptone supplemented with $0.1 \%(\mathrm{w} / \mathrm{v})$ of each mineral source. Cultivation was carried out for $96 \mathrm{~h}$ at $35^{\circ} \mathrm{C}, 200 \mathrm{rpm}$. Results represent the average of three independent experiments. Values were means of three determinations in five parallel experiments ( \pm standard deviations). * Statistically significant compared with the control $(* p<0.05)$. 

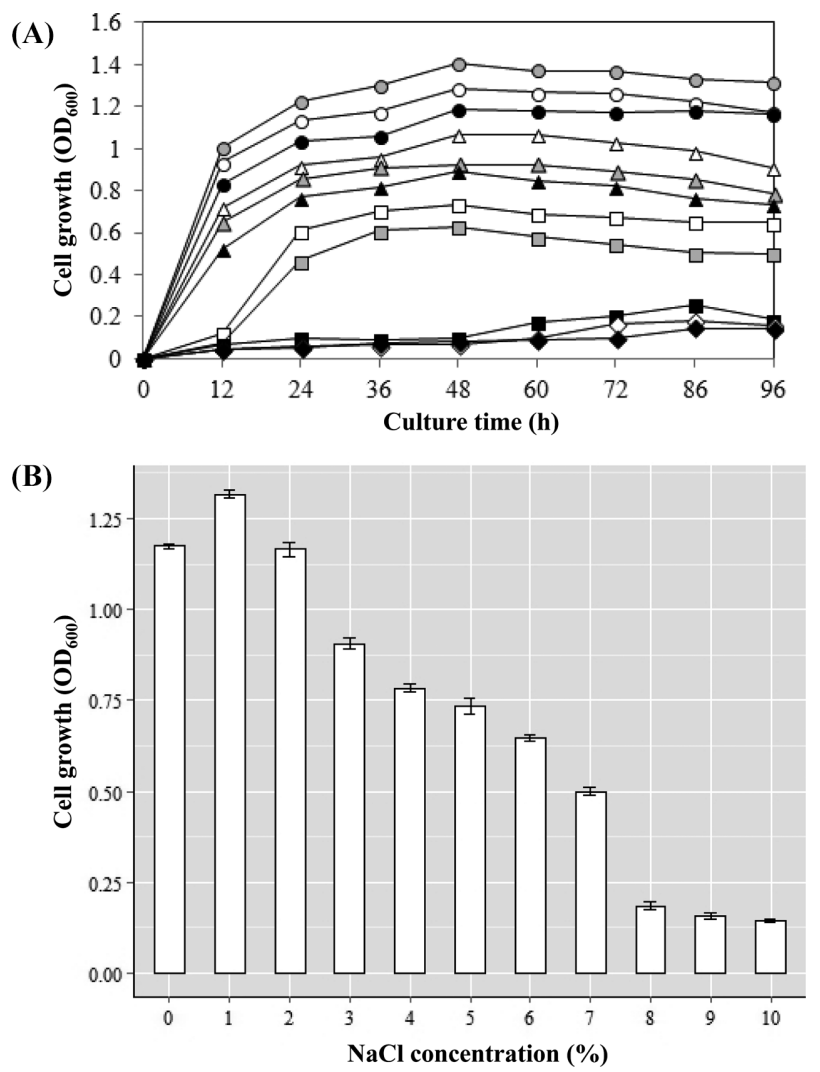

Fig. 1 Effect of $\mathrm{NaCl}$ concentration on cell growth by $B$. pumilus IJ-1. (A) Cultivation was carried out on A-medium containing $0.5 \%(\mathrm{w} / \mathrm{v})$ of tryptone with various $\mathrm{NaCl}$ concentrations for $96 \mathrm{~h}, 200 \mathrm{rpm}$ at $35^{\circ} \mathrm{C}$. Symbols: $\bigcirc, 0 \% ; \bigcirc, 1 \% ; \bigcirc, 2 \% ; \triangle, 3 \% ; \Delta, 4 \% ; \boldsymbol{\Delta}, 5 \% ; \square, 6 \%$; $7 \% ; \square, 8 \% ; \diamond, 9 \% ;>, 10 \%$ (B) B. pumilus $\mathrm{IJ}-1$ was incubated for $96 \mathrm{~h}$ with various $\mathrm{NaCl}$ concentrations. Results represent means of three independent experiments, and each bar represents the mean \pm SD.

하여 균주 생장과 표면장력을 측정하였다(Table 3). 첨가된 무 기염의 종류에 따라 초기 표면장력 값이 다르므로 배양 전 초 기의 표면장력과 배양 후 최종 표면장력의 값의 차이, 즉 표면 장력 감소율을 측정하였다.

각종 무기염이 첨가된 배지에서 B. pumilus $\mathrm{IJ}-1$ 의 $\mathrm{OD}_{600}$ 값 은 모두 1.0 이하로 이들은 대조구 $\left(\mathrm{OD}_{600}=2.188\right)$ 에 비해 낮은 생장을 보였다. 그리고 $0.5 \%(\mathrm{w} / \mathrm{v})$ tryptone에 각종 무기염을 첨가한 배지의 표면장력은 대조군에 비해 모두 유의적인 차이 를 나타내었다 $(* p<0.05)$. 표면장력 감소율은 $\mathrm{NaCl}(32.8 \pm 0.21$, $p<0.05)$ 과 $\mathrm{KCl}(33.6 \pm 0.26, p<0.05), \mathrm{KNO}_{3}(34.4 \pm 0.35, p<$ $0.05), \mathrm{H}_{3} \mathrm{BO}_{3}(34.0 \pm 0.05, p<0.05)$ 에서 각각 $45.1,44.7,43.4$, $43.1 \%$ 순으로 높게 조사되었으나 이들은 모두 대조구(52.0\%)보 다 낮게 나타나 무기염이 첨가된 배지는 생물계면활성제 생산 을 증가시키는데 부적합한 것으로 확인되었다.

$\mathrm{Kim}$ 등(1997)은 $\mathrm{K}_{2} \mathrm{HPO}_{4}$ 와 $\mathrm{NaH}_{2} \mathrm{PO}_{4}$ 를 7:1의 비율로 사용하 였을 때 B. subtilis C9의 생물계면활성제 생산이 가장 높다고 보고하였다. 그리고 여기에 $\mathrm{MnSO}_{4}$ 를 첨가하여 균주 생장과 생 물계면활성제 생산을 증가시켰으며, $\mathrm{CaCl}_{2}$ 와 $\mathrm{NaCl}$ 은 균주 생장 과 생물계면활성제 생산을 저해하는 것으로 나타났다. 한편, $B$. subtilis ATCC21332는 철과 망간을 배지에 첨가한 결과 생물계
(A)

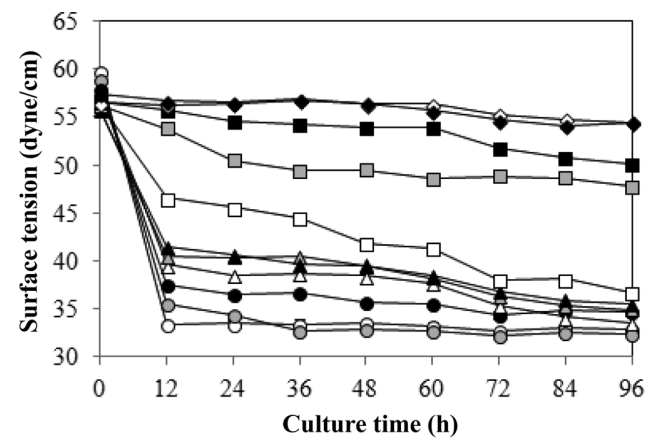

(B)

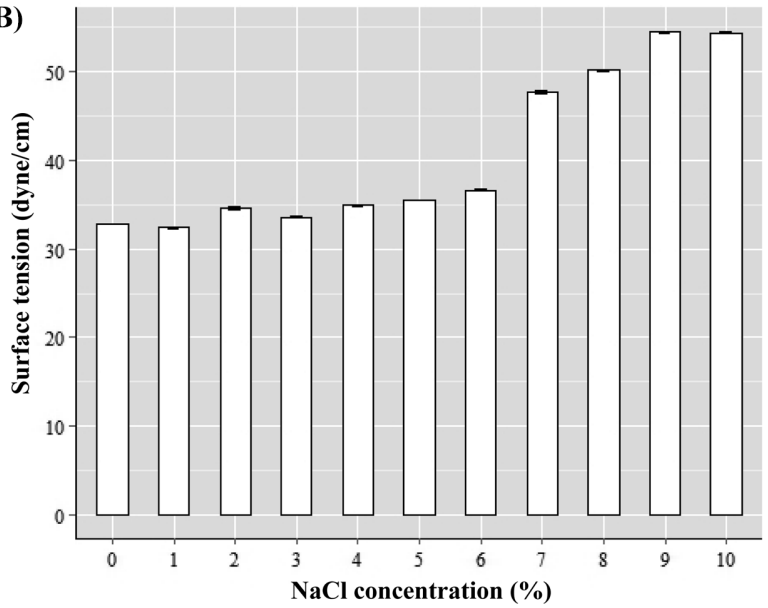

Fig. 2 Effect of $\mathrm{NaCl}$ concentration on surface tension of the biosurfactant produced by $\boldsymbol{B}$. pumilus IJ-1. (A) The cultivation was the same as Fig. 1. Symbols: $\bigcirc, 0 \% ; \bigcirc, 1 \% ; \bigcirc, 2 \% ; \triangle, 3 \% ; \Delta, 4 \%$; $\boldsymbol{\Delta}, 5 \% ; \square, 6 \% ; \square, 7 \% ; \square, 8 \% ; \diamond, 9 \% ; \diamond, 10 \%$ (B) Surface tension was determined for $96 \mathrm{~h}$ with various $\mathrm{NaCl}$ concentrations. Results represent means of three independent experiments, and each bar represents the mean $\pm \mathrm{SD}$.

면활성이 증가하였다(Wei 등, 2003).

B. pumilus IJ-1의 생물계면활성제 생산에 미치는 $\mathrm{NaCl}$ 농도 의 영향. 환경의 영향을 조사하기 위하여 다양한 $\mathrm{NaCl}$ 농도, 배 지의 초기 $\mathrm{pH}$ 및 배양 온도에 따른 균주 생장과 생물계면활성 제의 표면장력을 측정하였다.

B. pumilus IJ-1의 해수 적용 가능성을 검토하기 위하여 생물 계면활성제 생산에 미치는 $\mathrm{NaCl}$ 농도의 영향을 조사하였다. 본 균주는 충남 태안의 해안에서 분리한 것으로, 실험결과 $0-10 \%$ $(\mathrm{w} / \mathrm{v})$ 의 $\mathrm{NaCl}$ 농도에서 생장하였다. 특히, $0-2 \%(\mathrm{w} / \mathrm{v}) \mathrm{NaCl}$ 농도에서 배양하였을 때 가장 잘 생장하여, 배양 48시간에 최 고의 생육도를 나타내었다 $\left(\mathrm{OD}_{600}=1.2-1.4\right)$. 배지 내 $\mathrm{NaCl}$ 농도 가 높아질수록 균주 생장이 둔화되어 $10 \%(\mathrm{w} / \mathrm{v}) \mathrm{NaCl}$ 에서는 최저로 확인되었다(Fig. 1). 한편, 배지에 첨가된 $\mathrm{NaCl}$ 농도에 따른 균주의 생장과 생물계면활성제 생산은 거의 일치함을 확 인하였다. 또한 $\mathrm{NaCl}$ 농도는 B. pumilus $\mathrm{IJ}-1$ 의 생물계면활성제 생산에 영향을 미치는 것으로 조사되었다. 0-1\% (w/v) NaCl을 첨가한 배양액의 표면장력 값은 배양 72시간에 32.3-32.7 dyne/ $\mathrm{cm}$ 였다. 그리고 $2-3 \%(\mathrm{w} / \mathrm{v})$ 의 $\mathrm{NaCl}$ 농도에서는 최대 감소 표 면장력 값 33.6-34.3 dyne/cm을 유지하였고, 4-5\% (w/v) $\mathrm{NaCl}$ 농도에서는 34.9-35.5 dyne/cm을 나타내었다(Fig. 2). 이는 해수 
(A)

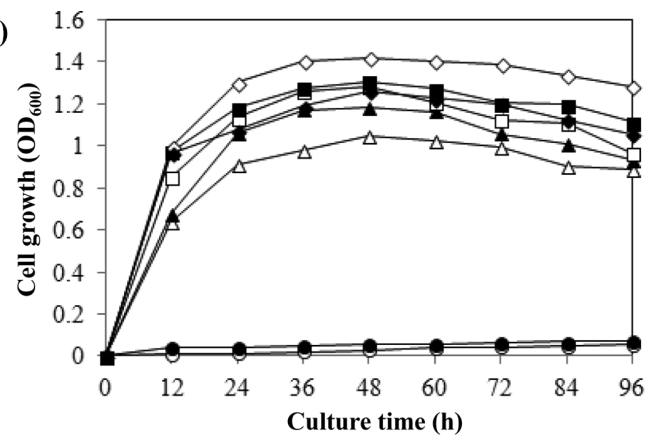

(B)

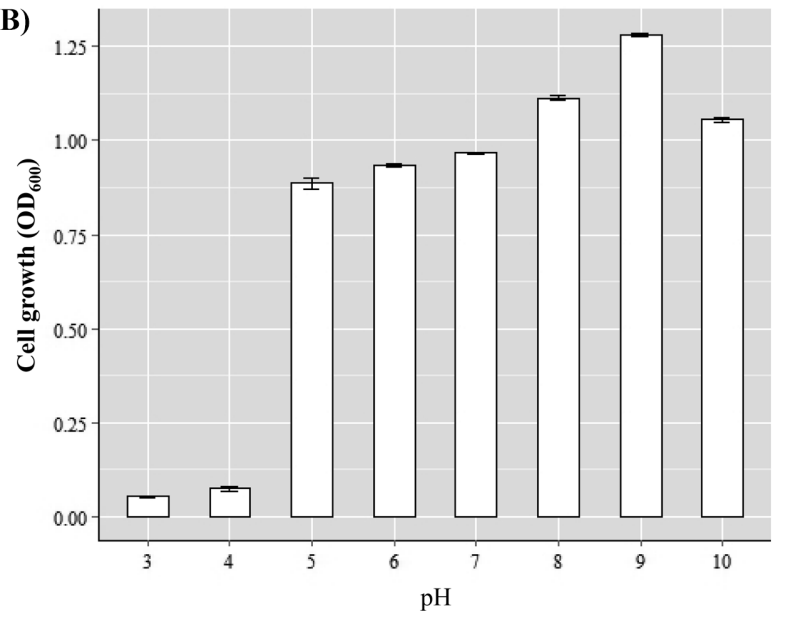

Fig. 3 Effect of initial $\mathbf{p H}$ of medium on cell growth by B. pumilus IJ1. (A) Cultivation was carried out on A-medium containing $0.5 \%(\mathrm{w} / \mathrm{v})$ of tryptone with various $\mathrm{pH}$ for $96 \mathrm{~h}, 200 \mathrm{rpm}$ at $35^{\circ} \mathrm{C}$. Symbols: $\bigcirc$, pH 3;, $\mathrm{pH} 4 ; \triangle, \mathrm{pH} 5 ; \boldsymbol{\Delta}, \mathrm{pH} 6 ; \square, \mathrm{pH} 7 ; \mathbf{\square}, \mathrm{pH} 8 ; \diamond, \mathrm{pH} 9 ; \diamond, \mathrm{pH} 10$ (B) B. pumilus IJ-1 was incubated for $96 \mathrm{~h}$ with various $\mathrm{pH}$. Results represent means of three independent experiments, and each bar represents the mean $\pm \mathrm{SD}$.

의 염 농도인 35\% (31-5 g/L)보다 높은 농도에서 균주의 생장 과 표면장력 활성을 나타내는 것으로, B. pumilus IJ-1은 해수 에 적용 가능하다고 사료되었다.

Pseudomonas sp. G314는 $1-3 \% \quad(\mathrm{w} / \mathrm{v}) \quad \mathrm{NaCl}$ 농도에서 25.8-27.5 dyne $/ \mathrm{cm}$ 의 표면장력 값을 나타내었다 (Shim과 Park, 2006). 한편, Haddad 등(2009)에 의하면 B. subtilis HOB2의 생물계면활성제는 $25 \%(\mathrm{w} / \mathrm{v}) \mathrm{NaCl}$ 농도에서도 안정하였다.

B. pumilus IJ-1의 생물계면활성제 생산에 미치는 초기 $\mathrm{pH}$ 의 영향. 현장에 적용되는 미생물은 다양한 $\mathrm{pH}$ 의 환경을 접하게 된다. B. pumilus $\mathrm{IJ}-1$ 은 산성과 알칼리성의 $\mathrm{pH}(\mathrm{pH} 5-10)$ 배 지에서 생장하였으며, $\mathrm{pH}$ 9인 배지에서 가장 높은 생육도를 나 타내었다. 반면에 초기 $\mathrm{pH}$ 3-4의 배지에서는 거의 생장하지 못 하였다(Fig. 3). 배지의 초기 $\mathrm{pH}$ 에 따른 표면장력을 측정한 결 과, B. pumilus $\mathrm{IJ}-1$ 은 $\mathrm{pH} 5$ 부터 10 까지 넓은 $\mathrm{pH}$ 범위에서 높 은 표면장력 활성을 나타내었다. 특히, $\mathrm{pH}$ 9에서는 배양 72 시 간에 $30.5 \mathrm{dyne} / \mathrm{cm}$ 로 가장 우수한 표면장력 활성을 확인할 수 있었다. 이와는 달리, $\mathrm{pH}$ 3과 4에서 배양한 경우 배양 시간이 경과할수록 표면장력 값이 감소하지 않아 산성 조건은 생물계 면활성제 생산에 적합하지 못하다고 사료되었다(Fig. 4). 이와 같이 산성 조건 하에서 생물계면활성제의 활성이 상대적으로 낮 은 현상에 대하여 Wei 등(2003)은 세포 외로 분비되는 산성 대
(A)
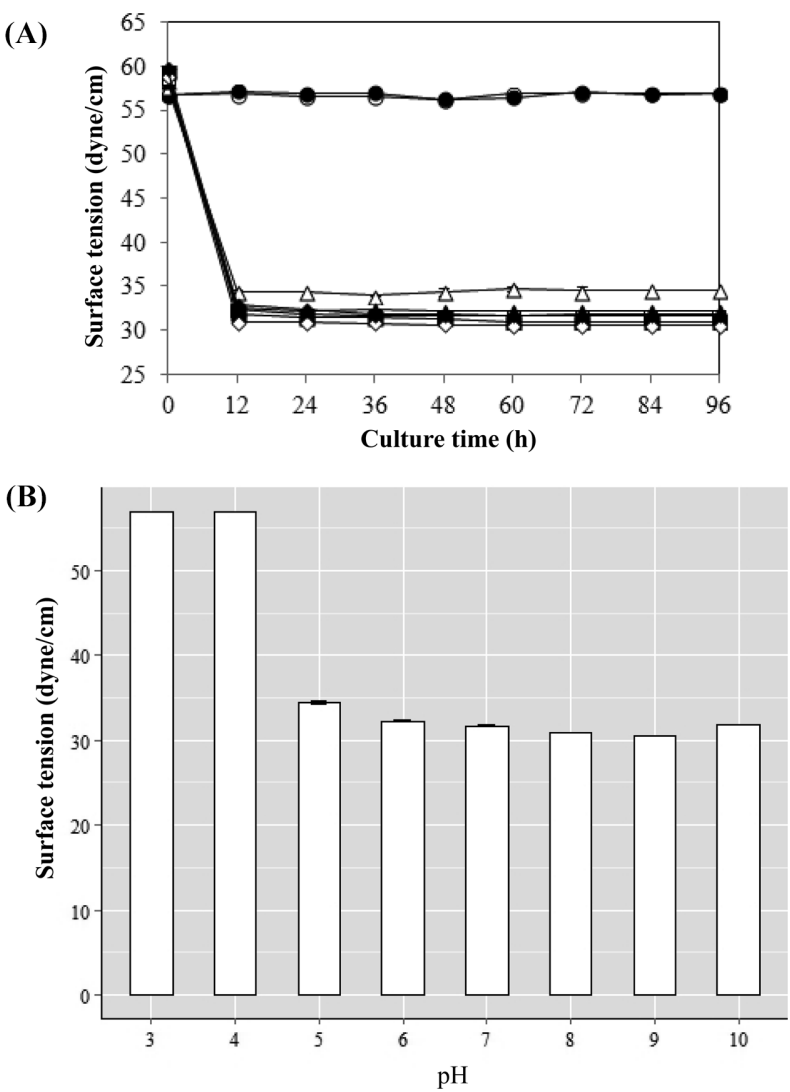

Fig. 4 Effect of initial pH of medium on surface tension of the biosurfactant produced by $\boldsymbol{B}$. pumilus IJ-1. (A) The cultivation was the same as Fig. 3. Symbols: $\mathrm{pH} 3 ; \mathbf{\bigcirc}, \mathrm{pH} 4 ; \triangle, \mathrm{pH} 5 ; \boldsymbol{\Delta}, \mathrm{pH} 6 ; \square, \mathrm{pH}$ 7; $\mathbf{\square}, \mathrm{pH} 8 ; \diamond, \mathrm{pH} 9 ; \diamond, \mathrm{pH} 10$ (B) Surface tension was determined for $96 \mathrm{~h}$ with various $\mathrm{pH}$. Results represent means of three independent experiments, and each bar represents the mean $\pm \mathrm{SD}$.

사물질들의 축적에 의해 생물계면활성제가 침전되기 때문이라 고 설명하였다. 한편, Bacillus sp. BJS-51의 생물계면활성제 생 산을 위한 최적 $\mathrm{pH}$ 는 7.2이었다(Kim 등, 2005). 그리고 Haddad 등(2009)은 B. subtilis HOB2의 생물계면활성제 생산을 위한 $\mathrm{pH}$ 는 5.0-11.0이라고 보고하였다.

일반적인 해수의 $\mathrm{pH}$ 는 약알칼리성이며, 미생물이 생산하는 생물계면활성제에 의해서 해수의 $\mathrm{pH}$ 는 거의 영향을 받지 않아 야 하는 것(Walker와 Colwell, 1975)을 감안하면, B. pumilus IJ-1은 해수의 유류 오염 정화에 활용 가능성이 높다고 판단된다.

B. pumilus IJ-1의 생물계면활성제 생산에 미치는 온도의 영향. 미생물로부터 생산되는 생물계면활성제는 온도 변화에 많은 영 향을 받는 것으로 알려져 있다(Dibble과 Bartha, 1979). $B$. pumilus IJ-1은 비교적 넓은 범위의 온도 $\left(20-45^{\circ} \mathrm{C}\right)$ 에서 생장하 였으며, 그 중 $35^{\circ} \mathrm{C}$ 에서 가장 잘 생장하였다. 그리고 20,25 , $30^{\circ} \mathrm{C}$ 에서는 유사한 생장 패턴을 나타내었으며, 40 과 $45^{\circ} \mathrm{C}$ 에서 는 상대적으로 낮은 생장을 보였다. 반면에 15 와 $50^{\circ} \mathrm{C}$ 에서는 거의 생장하지 않는 것으로 확인되었다(Fig. 5). 배양 온도에 따 른 표면장력을 시간대별로 조사한 결과, 균주 생장이 좋은 20 $35^{\circ} \mathrm{C}$ 에서 표면장력 활성은 높게 나타났다. 특히, $20^{\circ} \mathrm{C}$ 에서의 표 면장력은 배양 72 시간에 $28.4 \mathrm{dyne} / \mathrm{cm}$ 로 측정되어 가장 우수한 표면활성을 나타내었다. 또한, 25,30 과 $35^{\circ} \mathrm{C}$ 에서의 최저 표면 

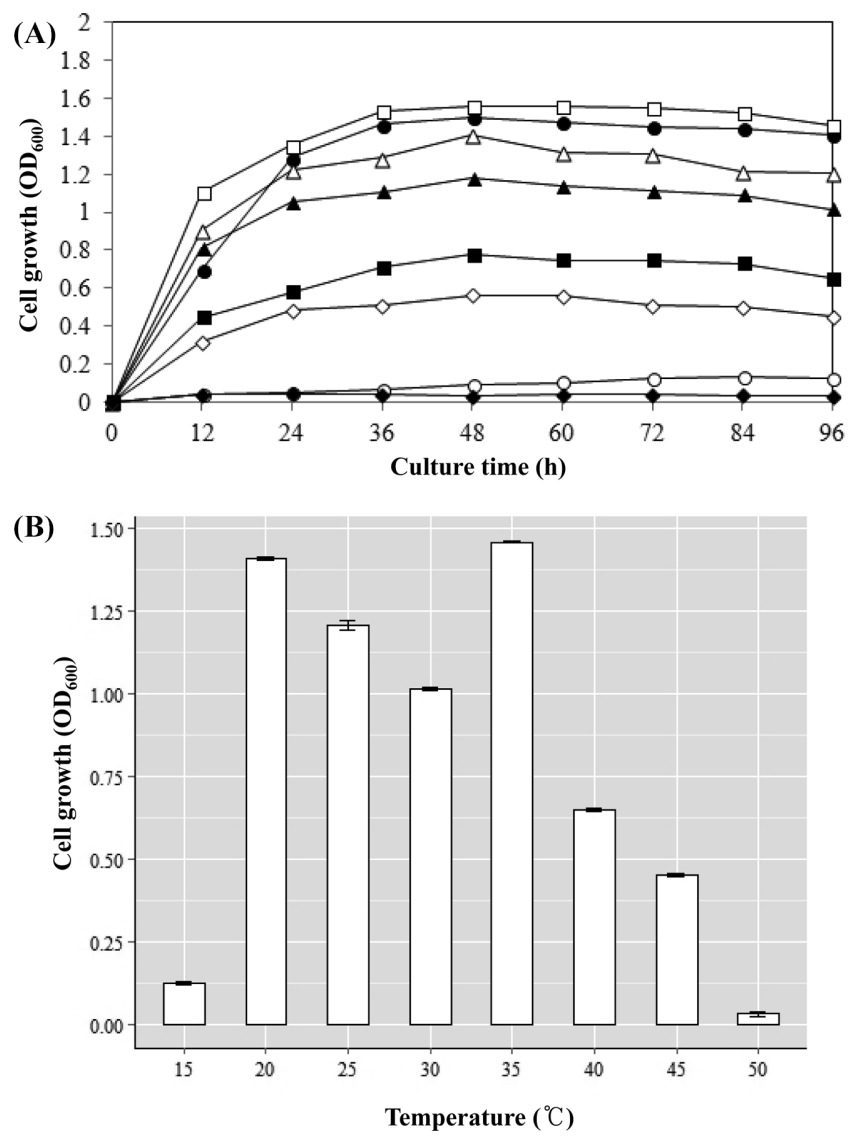

Fig. 5 Effect of culture temperature on cell growth by B. pumilus IJ1. (A) Cultivation was carried out on A-medium containing $0.5 \%(\mathrm{w} / \mathrm{v})$ of tryptone for $96 \mathrm{~h}, 200 \mathrm{rpm}$ at various temperatures. Symbols: $\bigcirc$, $15^{\circ} \mathrm{C} ; \bigcirc, 20^{\circ} \mathrm{C} ; \triangle, 25^{\circ} \mathrm{C} ; \boldsymbol{\Delta}, 30^{\circ} \mathrm{C} ; \square, 35^{\circ} \mathrm{C} ; \square, 40^{\circ} \mathrm{C} ; \diamond, 45^{\circ} \mathrm{C} ;$ $50^{\circ} \mathrm{C}$ (B) B. pumilus IJ-1 was incubated for $96 \mathrm{~h}$ with various temperatures. Results represent means of three independent experiments, and each bar represents the mean \pm SD.

장력 값은 29.4 dyne $/ \mathrm{cm}(72 \mathrm{~h}), 32.1 \mathrm{dyne} / \mathrm{cm}(60 \mathrm{~h})$ 와 35.5 dyne $/ \mathrm{cm}$ (72 h)로 각각 측정되었다. 반면에 15 와 $50^{\circ} \mathrm{C}$ 는 생물 계면활성제 생산에 적합하지 않은 온도로 확인되었다(Fig. 6).

B. subtilis C9 (Kim, 1997), B. subtilis MTCC1427 (Makkar 와 Cameotra, 1998), B. licheniformis VKMB-511 (Gogotov와 Miroshnikov, 2009)의 생물계면활성제 생산을 위한 최적 온도는 $30^{\circ} \mathrm{C}$ 이었다. 일반적으로 유류가 유출된 지역에 미생물을 사용 하여 오염 물질을 정화하기 위해서는 활용 지역의 온도에서 활 성을 유지해야 할 필요성이 있다. 우리나라 해양의 수온은 1$28^{\circ} \mathrm{C}$ 이며, 해양세균들은 일반적으로 생육온도가 $20^{\circ} \mathrm{C}$ 전후이 다. 따라서 본 실험에 사용된 B. pumilus IJ-1은 해양의 유류오 염 정화에 사용할 수 있을 것으로 생각된다.

계면활성제가 표면에 흡착되면 표면장력 강하가 일어난다. 따 라서 계면활성제의 성능에 대해서 이야기할 때에는 반드시 표 면장력 강하를 언급해야 한다. 일반적으로 계면활성제로 성능이 좋다고 말하려면 표면장력은 $30 \mathrm{dyne} / \mathrm{cm}$ 정도로 낮출 수 있어 야 하며(Lang, 2002), 화학적 계면활성제는 표면장력이 25-50 dyne $/ \mathrm{cm}$ 의 값을 가진다(Mulligan, 2005). 본 연구를 통해 $B$. pumilus IJ-1이 생물계면활성제를 효율적으로 생산하기 위한 최
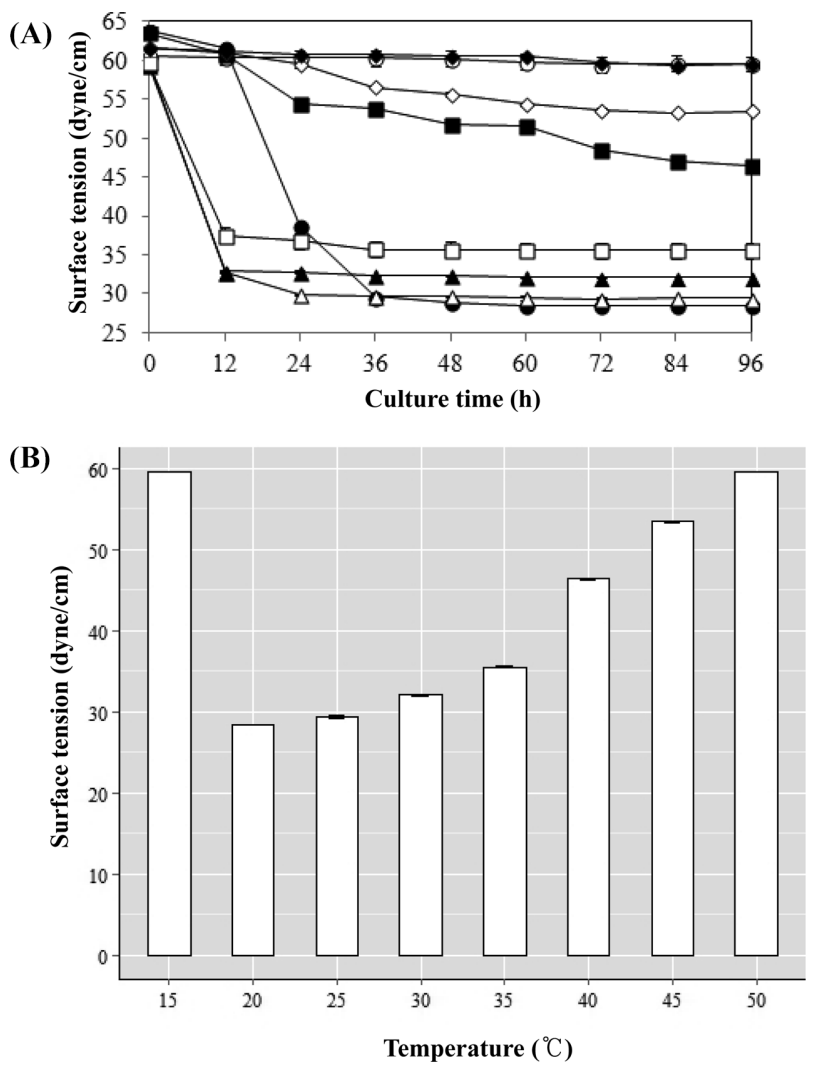

Fig. 6 Effect of culture temperature on surface tension of the biosurfactant produced by $\boldsymbol{B}$. pumilus IJ-1. (A) The cultivation was the same as Fig. 5. Symbols: $\bigcirc, 15^{\circ} \mathrm{C} ; \bigcirc, 20^{\circ} \mathrm{C} ; \triangle, 25^{\circ} \mathrm{C} ; \boldsymbol{\Delta}, 30^{\circ} \mathrm{C} ; \square$, $35^{\circ} \mathrm{C} ; \square, 40^{\circ} \mathrm{C} ; \diamond, 45^{\circ} \mathrm{C} ; \diamond, 50^{\circ} \mathrm{C}$ (B) Surface tension was determined for $96 \mathrm{~h}$ with various temperatures. Results represent means of three independent experiments, and each bar represents the mean \pm SD.

적의 배지 조성은 $0.5 \%(\mathrm{w} / \mathrm{v})$ tryptone을 함유한 A-배지인 것 으로 결정되었다. 이 조건 하에서 72 시간 동안 배양된 배양액 을 가지고 최적 배양 환경인 $20^{\circ} \mathrm{C}, \mathrm{pH}$ 9에서 표면장력을 측정 한 결과, 27.0 dyne/cm로 조사되었다(data not shown). 이는 $B$. subtilis C9 (28.2 dyne/cm) (Kim 등, 1997), B. subtilis MTCC1427 (28.0 dyne/cm) (Makkar와 Cameotra, 1998), Bacillus sp. BJS51 (29 dyne/cm) (Kim 등, 2005), B. subtilis YRE207 (31.5 dyne $/ \mathrm{cm}$ ) (Fonseca 등, 2007)의 최저 표면장력 값 보다 더 낮 은 것으로 확인되었다.

본 실험 결과에 의하면 배지에 첨가되는 tryptone은 다른 배 지 성분에 비해 B. pumilus IJ-1의 생물계면활성제 생산에 더 많은 영향을 미치는 것으로 조사되었다. 따라서 tryptone을 대 체할 만한 경제적인 질소원을 확립하는 것이 필요하다고 판단 되며, 특히 폐질소원 기질을 생물계면활성제 생산에 이용한다면 환경적인 측면과 자원 재활용 측면에서 많은 이점이 있을 것으 로 사료된다. 또한 본 실험에 사용된 B. pumilus IJ-1은 광범위 한 온도와 $\mathrm{pH}, \mathrm{NaCl}$ 농도에서 생육과 생물계면활성제 생산성 이 뛰어나 오염된 자연환경이나 해수에 적용시켜 환경정화에 사 용하기에 우수한 균주임을 확인하였다. 이번 연구는 B. pumilus IJ-1의 생물계면활성제 생산을 위한 배양 조건에 대한 기초 데 이터로서 최적 환경 조건을 결정하기 위한 추가적인 연구가 계 
속 진행되어야 할 것으로 생각되어, 현재 본 연구의 결과들을 토대로 반응표면분석법을 이용한 통계학적인 연구가 진행 중이다.

\section{초 록}

Bacillus pumilus IJ-1의 생물계면활성제 생산을 위한 배지 조성 의 특성을 조사하기 위하여 다양한 탄소원, 질소원 및 무기염 이 미치는 영향을 검토하였다. 그 결과 B. pumilus $\mathrm{IJ}-1$ 은 $0.5 \%$ (w/v) tryptone을 첨가하여 배양하였을 때 가장 많은 생물계면 활성제를 생산하였다. B. pumilus $\mathrm{IJ}-1$ 은 $0-10 \%(\mathrm{w} / \mathrm{v})$ 의 $\mathrm{NaCl}$ 농도와 $\mathrm{pH} 5-10,20-45^{\circ} \mathrm{C}$ 의 환경에서 생장이 가능하였다. 그 리고 생물계면활성제 생산은 $\mathrm{pH} 9.0$ 의 초기 배지에서 $20^{\circ} \mathrm{C}, 72$ 시간 동안 배양했을 때 최대였으며, 이러한 배양 조건 하에서 얻어진 배양액의 표면장력은 $27.0 \mathrm{dyne} / \mathrm{cm}$ 이었다.

Keywords 배양 조건·배지 조성·생물계면활성제·표면장력· Bacillus pumilus IJ-1

\section{References}

Ahimou F, Jacques P, and Deleu M (2000) Surfactin and iturin A effects on Bacillus subtilis surface hydrophobicity. Enzyme Microb Technol 27, 749-54.

Banat IM, Makkar RS, and Cameotra SS (2000) Potential commercial applications of microbial surfactants. Appl Microbiol Biotechnol 53, 495-508.

Bognolo G (1999) Biosurfactants as emulsifying agents for hydrocarbons. Colloids Surf A Physicochem Eng Asp 152, 41-52.

Deshpande S, Shiau BJ, Wade D, Sabatini DA, and Harwell JH (1999) Surfactant selection for enhancing ex situ soil washing. Water Res $\mathbf{3 3}$, $351-60$.

Dibble JT and Bartha R (1979) Effect of environmental parameters on the biodegradation of oil sludge. Appl Environ Microbiol 37, 729-39.

Fonseca RR, Silva AJ, De França FP, Cardoso VL, and Sérvulo EF (2007) Optimizing carbon/nitrogen ratio for biosurfactant production by a Bacillus subtilis strain. Appl Biochem Biotechnol 137-140, 471-86.

Ghojavand H, Vahabzadeh F, Roayaei E, and Shahraki AK (2008) Production and properties of a biosurfactant obtained from a member of the Bacillus subtilis group (PTCC 1696). J Colloid Interface Sci 324, 172-6.

Gogotov IN and Miroshnikov AI (2009) The influence of growth medium composition and physicochemical factors on biosurfactant production by the bacterium Bacillus licheniformis VKM B-511. Prikl Biokhim Mikrobiol 45, 654-8.

Greek BF (1991) Sales of detergents growing desoite recession. Chem Eng
News 69, 25-52.

Haddad NI, Wang J, and Mu B (2009) Identification of a biosurfactant producing strain: Bacillus subtilis HOB2. Protein Pept Lett 16, 7-13.

Hassanshahian M, Emtiazi G, and Cappello S (2012) Isolation and characterization of crude-oil-degrading bacteria from the Persian Gulf and the Caspian Sea. Mar Pollut Bull 64, 712.

Hur SH, Yang JS, and Hong JH (2002) Production of biosurfactant using Bacillus spp.. J Korean Soc Food Sci Nutr 31, 389-93.

Joshi S, Bharucha C, and Desai AJ (2008) Production of biosurfactant and antifungal compound by fermented food isolate Bacillus subtilis $20 \mathrm{~B}$. Bioresour Technol 99, 4603-8.

Kim HS, Yoon BD, Lee CH, Suh HH, Oh HM, Katsuragi T et al. (1997) Production and properties of a lipopeptide biosurfactant from Bacillus subtilis C9. J Ferment Bioeng 84, 41-6.

Kim JS, Song HS, Chung NH, and Bang WG (2005) Optimization of production conditions of biosurfactant from Bacillus sp. and its purification. J Korean Soc Appl Biol Chem 48, 109-14.

Kim JY (2014) Isolation and characterization of a biosurfactant-producing bacterium Bacillus pumilus IJ-1 from contaminated crude oil collected in Taean, Korea. J Korean Soc Appl Biol Chem 57, 514.

Lang S (2002) Biological amphiphiles (microbial biosurfactants). Curr Opin Colloid Interface Sci 7, 12-20.

Makkar RS and Cameotra SS (1998) Production of biosurfactant at mesophilic and thermophilic conditions by a strain of Bacillus subtilis. $J$ Ind Microbiol Biotechnol 20, 48-52.

Mukherjee S, Das P, and Sen R (2006) Towards commercial production of microbial surfactants. Trends Biotechnol 24, 509-15.

Mulligan CN (2005) Environmental applications for biosurfactants. Environ Pollut 133, 183-98.

Najkar D and Gutnick DL (2003) Involvement of a protein tyrosine kinase in production of the polymeric bioemulsifier emulsan from the oildegrading strain Acinetobacter lwoffii RAG-1. J Bacteriol 185, 1001-9.

Pagilla KR, Sood A, and Kim H (2002) Gordonia (nocardia) amarae foaming due to biosurfactant production. Water Sci Technol 46, 519-24.

Pirog TP, Shevchuk TA, Voloshina IN, and Karpenko EV (2004) Production of surfactants by Rhodococcus erythropolis strain EK-1, grown on hydrophilic and hydrophobic substrates. Appl Biochem Microbiol 40, 470-5.

Sahoo S, Datta S, Biswas D, and Banik Choudhury R (2010) Biosurfactant production from n-paraffins by an air isolate Pseudomonas aeruginosa OCD1. J Oleo Sci 59, 601-5.

Shim SH and Park KR (2006) Characteristics of biosurfactant producing Pseudomonas sp. G314. Kor J Mocrobiol 42, 286-93.

Thavasi R, Jayalakshmi S, Balasubramanian T, and Banat IM (2007) Biosurfactant production by Corynebacterium kutscheri from waste motor lubricant oil and peanut oil cake. Lett Appl Microbiol 45, 686-91.

Walker JD and Colwell RR (1975) Some effect of petroleum on estuarine and marine microorganisms. Can J Microbiol 21, 305-13.

Wei YH, Wang LF, Changy JS, and Kung SS (2003) Identification of induced acidification in iron-enriched cultures of Bacillus subtilis during biosurfactant fermentation. J Biosci Bioeng 96, 174-8. 